\title{
FILM REVIEW
}

Karim Moussaoui, dir. Until the Birds Return. 2017. Original title: En Attendant les Hirondelles. 113 minutes. Arabic/French. Production: Les Films Pelléas and Arte (France); Niko (Germany); and Prolégomènes (Algeria). French distribution: Ad Vitam (France). International distribution: MK2 Films. No Price Reported.

Until the Birds Return, directed by Karim Moussaoui, is a testimony to individual desire and group violence embedded in bruised hopes. The movie is a reflection on the nature of time: time spent over a week, in different parts of Algeria and flowing smoothly around a road trip, exploring the human soul of a country struggling to survive the atrocities of the bloody decade of Civil War that traumatized Algeria from 1991 to 2002. The film is in three acts: three characters, three generations, three stories, and each time, a moral dilemma to be resolved.

In the first act we encounter Mourad, an older real estate developer dividing his time between his ex-wife and his current wife, who is French and feels neglected and homesick. One evening when he returns home, he witnesses the vicious beating of a man by thugs and feels guilty for not providing assistance to a person in immediate and grave danger. Act Two focuses on Aisha, from a middle-class family, who is being driven to the south of the country to meet her future husband, a cousin, while she struggles to contain her desire for the driver, Djalil. The final act addresses the plight of Dahman, a neurologist. On the eve of his wedding, Dahman is accosted by a woman who accuses him of being one of the soldiers who gang-raped her during the war and who is possibly the father of her mute and traumatized boy.

Until the Birds Return is an allegory for the lethargic reception of the "Arab Spring," which swept through Tunisia and Egypt and the rest of the Arab World in early 2011. In the case of Algeria, Moussaoui's film gestures toward powerful disciplinary mechanisms that produce forms of self-policing and self-discipline. Moussaoui centers the movie on the act of waiting for the thing that will never come. This is to underscore a general feeling of being detached from reality and numbness in a context of extreme precarity. All of these elements together indicate a general lack of emotional literacy and productive forms of agency, which are dear to scholars such as Martha Nussbaum.

What is more, the film depicts lives complicated by the consequences of French colonial rule, the difficulties of the post-colonial transition, and the 
civil war of the 1990s, all of which continue to haunt the Algerian nation. The viewer sees this with Lila, Mourad's ex-wife, who deplores a country "paralyzed" in the image of the ghost buildings surrounding Algiers, whose construction has stopped. This could be understood as representative of an unexamined haunted past which continues to weigh in on contemporary social relations in terms of denial, amnesia, and guilt. In aggregate, Moussaoui's work demonstrates a dynamic interaction between personal and collective traumas in a country that has trouble completely erasing the violence of the past. Consequently, it insists on the necessity, on both a national and a civil level, of confronting the wrongdoings of the past, as a precondition for national healing and reconciliation.

Until the Birds Return is a cinematic essay on survival strategies, suggesting that denial, aloofness, and conformity must make way for productive forms of communal intimacy and the equal redistribution of the sensible. It invites the audience to make sense of the painful events depicted in the film by resisting a regime of perception that keeps the vulnerable and the marginalized out of sight. Moussaoui challenges the dominant power to frame and propagate normative forms of the "real and unreal," the "grievable and ungrievable," and to open pathways for authentic self-understanding.

The film succeeds in creating an atmosphere, visuals, and mood that are infinitely lighter, while paying tremendous attention to detail, language, gestures, faces, places, and music in scenes such as the one in which Djalil and Aicha dance sensually in an empty bar and, later, when they have a pivotal rendezvous with a marching band reminiscent of Leos Carax's Holy Motors (2012). Toward the end of the movie as well, Dahman's wedding scenes show the grace of Algerian bodies that are liberated by dancing under cosmopolitan cultural influences ranging from baroque exultation to languor that links Johann Sebastian Bach to Raïna Raï. These kinds of scenes make visible and audible conditions of possibilities for what Giorgio Agamben calls the "coming community." Such a "coming community" will be a redeemed world without exclusion and a place to generate forms of productive solidarity.

Olivier Tchouaffe University of Texas at Austin

Austin, Texas

doi:10.1017/asr.2018.113

tchouaffe@utexas.edu 